\title{
HALITOSIS ACTIVITY AGAINST VOLATILE SULFUR COMPOUND OF METHYL MERCAPTAN COMPONENT FROM BURAHOL (STELECHOCARPUS BURAHOL) FRUIT EXTRACT
}

\author{
ASNI AMIN ${ }^{1,2}$, MAKSUM RADJI ${ }^{3 *}$, ABDUL MUN'IM ${ }^{2}$, ANTON RAHARDJO $^{4}$, HERMAN SURYADI $^{5}$ \\ ${ }^{1}$ Laboratory of Pharmacognosy and Phytochemistry, Faculty of Pharmacy, University Moeslem of Indonesia, Indonesia. ${ }^{2}$ Laboratory \\ of Pharmacognosy and Phytochemistry, Faculty of Pharmacy, University of Indonesia, Indonesia, ${ }^{3}$ Laboratory of Pharmaceutical \\ Microbiology, Faculty of Pharmacy, University of Indonesia, Indonesia. ${ }^{4}$ Department of Preventive and Public Health Dentistry, Faculty \\ of Dentistry, University of Indonesia. ${ }^{5}$ Laboratory of Pharmaceutical Chemistry, Faculty of Pharmacy, University of Indonesia, \\ Indonesia. \\ Email: maksumradji@gmail.com
}

Received: 25 October 2016, Revised and Accepted: 08 February 2017

ABSTRACT

Objective: This research was conducted to prove the activity of Stelechocarpus burahol fruit (SBF) extracts against volatile sulfur compound (VSC) of methyl mercaptan in anaerobic Gram-negative oral bacteria causing halitosis.

Materials and Methods: Burahol fruits were extracted by ethanol and partitioned by several solvents and then identified the chemical constituents of the extracts using phytochemical screening test and polyphenol content by spectroscopic ultraviolet instrument. The halitosis activity against VSC of methyl mercaptan component derived from anaerobic Gram-negative oral bacteria after administration of SBF extracts with a dose of $20 \mathrm{mg} / \mathrm{ml}$ was conducted in vitro using gas chromatography-oral chroma.

Results: All extracts (ethanol, ethyl acetate, butanol, water, and methanol) contain flavonoids and polyphenols, whereas saponin was found in all extracts except methanol. Halitosis activity shows the ethanol extract of SBF, has absorption capability against methyl mercaptan, and was higher than the other extracts, with catechins as control.

Conclusion: All extracts of SBF (ethanol, ethyl acetate, butanol, water, and methanol) can inhibit and reduce VSC of methyl mercaptan causing halitosis.

Keywords: Stelechocarpus burahol, Methyl mercaptan, Halitosis.

(c) 2017 The Authors. Published by Innovare Academic Sciences Pvt Ltd. This is an open access article under the CC BY license (http://creativecommons. org/licenses/by/4. 0/) DOI: http://dx.doi.org/10.22159/ajpcr.2017.v10i5.15862

\section{INTRODUCTION}

Halitosis or oral malodor is a condition that describes the presence of smells or bed odor when breathing. Halitosis independently of the odoriferous substances and of their source, which can be oral or extraoral $[1,2]$. Approximately, the incidence of halitosis is about $30 \%$ worldwide [3]. In some participants, halitosis problem could cause social problems in confidence and shame when communicating with others. As a result, people affected by halitosis avoid social interaction and affected psychologically [4]. The main cause of oral malodor may be associated with health problems, such as diseases of the oral cavity, the accumulation of food debris and dental bacterial plaque on the teeth, or due to disorders of gastrointestinal tract, some of systemic diseases and metabolic disorders $[2,5,6]$.

Approximately $85-90 \%$ of halitosis occurs in the oral cavity, caused by the production of volatile sulfur compounds (VSC) such as hydrogen sulfide $\left(\mathrm{H}_{2} \mathrm{~S}\right)$, dimethyl sulfide $\left(\left(\mathrm{CH}_{3}\right)_{2} \mathrm{~S}\right)$, and methyl mercaptan $\left(\mathrm{CH}_{3} \mathrm{SH}\right)$, produced by oral anaerobic microbes $[7,8]$

Several herbals have been used as mouth deodorant to treat halitosis. Burahol fruit is one of the plants in Indonesia that has been empirically used by the princes of the palace of Jogjakarta as deodorant. Burahol fruits can make the body odor becomes fragrant, the breath becomes fragrant and even can also scent the smell of urine [9]. As an oral deodorant, burahol fruit serves as an adsorbent material and as a prebiotic. Burahol fruit also showed activity in reducing the levels of ammonia and methyl mercaptan for $62.9 \%$ and $77.8 \%$, respectively [10]. The preliminary studies conducted by Munim, 2013, showed that the ethanolic extract of burahol having activity able to absorb methyl mercaptan as the highest at $83.3 \%$, followed by butanol extract of $64.56 \%$ and $53.74 \%$ of water extracts [11].
This study was conducted to determine whether the burahol fruit extracts have the effect of eliminating halitosis using oral chroma (OC) [12].

\section{MATERIALS AND METHODS}

\section{Material}

Stelechocarpus burahol fruits (SBFs) were collected from Magelang District, Central Java, Indonesia. Determination of plant material was carried out by Indonesian Institute of Sciences, Center for Plant Conservation-Bogor Botanical Gardens, Bogor, Indonesia, under the code number 1557/IPH.3/KS/IV/2014. Saliva from six healthy participants in physiologic halitosis (who has passed the Ethics Committee by Tim Ethics Dentistry, Faculty of Dentistry-University of Indonesia, Indonesia), Porphyromonas gingivalis bacteria strain American Type Culture Collection (ATCC) 33277, Fusobacterium nucleatum bacteria strain ATCC 25586 (Medimark C Europe, France), solvents ( $96 \%$ ethanol, methanol, n-hexane, and butanol) were purchased from Bratachem, Indonesia, gas pack anaerobic (Thermo Scientific), gallic acid reagent from Merck (Elo Karsa, Indonesia), catechin reagents from Sigma-Aldrich (gift from BPPT, Indonesia), Fioroni paper sterile with diameter of $12.7 \mathrm{~mm}$, and physiological saline were used in the study.

\section{Instrument}

Gas chromatography-OC (GC-OC) (ATP), incubator (Memmert, German), dry oven (Memmert, German), rotary vacuum evaporator (IKA Werkw Rvor), and ultraviolet visible (UV-Vis) spectrophotometer (Hitachi U-2000, Japan) were used in the study.

\section{Extraction}

S. burahol flesh fruit was sliced and put into oven-dried fruit. SBF was dried in an oven (Memmert, Germany) at $40^{\circ} \mathrm{C}$ for 1 week. The dried powdered plant material (50.02 kg) was extracted with $96 \%$ 
ethanol in maceration vessel at room temperature. The extraction was done following the methods of the standardization of extract parameters [13]. The solution was filtered and evaporated in a rotary evaporator under reduced pressure at $50^{\circ} \mathrm{C}$ to yield a residue $(5.2 \mathrm{~kg})$ crude extract. The extract was partitioned in different solvents to separate the extract based on polarity. A total of $1002 \mathrm{~kg}$ crude ethanolic extract was partitioned with n-hexane solvent to yield n-hexane $(9.1 \mathrm{~g})$, ethyl acetate (45.02 g), n-butanol (227.9 g), and water (189.7 g) extract. About $80 \mathrm{~g}$ water extract obtained then condensed and dispersed into methanol to obtain methanol extract with higher polarity. The yield of methanol extract obtained was $29.7 \mathrm{~g}$. Each extract was then tested the halitosis activity against VSC of methyl mercaptan.

\section{Phytochemical screening}

The extracts were redissolved in distilled water and methanol; the each extract was used for the qualitative analysis of determination of secondary metabolites (alkaloids, flavonoids, tannins, saponins, steroids/terpenoids, and glycosides). The procedures for all chemical compounds were done according to the protocols described by Trease and Evans [14] and Tyler et al. [15].

\section{Total polyphenolic content}

The total phenolic content (TPC) of extracts was determined by Folin-Ciocalteu method as described by Singleton and Rossi [16] with some modifications. Each extract $(50 \mathrm{mg} / \mathrm{ml})$ was diluted with a suitable solvent and the volume up to $10 \mathrm{ml} .2 \mathrm{ml}$ of each solution was taken and poured it into the test tube, $1.6 \mathrm{ml}$ of distilled water and $0.2 \mathrm{ml}$ of Folin-Ciocalteu reagent $(50 \% \mathrm{v} / \mathrm{v})$ were added, was shaken to make homogeneous for 1 minute using a vortex and let stand for 4 minutes. Then, $4 \mathrm{ml}$ of sodium carbonate $(11 \% \mathrm{w} / \mathrm{v})$ was added, centrifuged for 10 minutes, and incubated for $2 \mathrm{hrs}$ in dark at room temperature. The TPC compound was expressed as milligram of gallic acid equivalents/gram dry extract. The absorbance was measured at $765 \mathrm{~nm}$ using a UV-Vis spectrophotometer. The mean values and standard deviations ( \pm ) results of triplicate analyses.

\section{Halitosis activity assay against VSC of methyl mercaptan from SBF extracts}

Halitosis activity test carried out in vitro by measuring the ability of the extract in inhibiting or reducing gas volatile methyl mercaptan causes of halitosis, which is produced by the Gram-negative anaerobic bacteria obtained from halitosis physiological participants' saliva. Salivary from six participants of halitosis physiological who passed the Ethics Committee by Tim Ethics Dentistry, Faculty of Dentistry - UI with inclusion criteria: Male or healthy women, aged 20-45 years, halitosis derived from intraoral (halitosis physiological), they do not have carious dentin or dental caries open, participants willing to participate in the study, and following the procedures established by signing an informed consent form.

Before taking saliva, participants were required fasted from meal for $8 \mathrm{hrs}$, and they do not rinse and brush their teeth during fast to get the condition of physiological halitosis. Saliva was taken in the morning when participants wake up $(05.00 \mathrm{am})$. Saliva from the participants was taken in tongue and periodontal area using sterile oral swab under aseptic condition. Saliva inserted in tube $(2 \mathrm{ml})$ containing $1 \mathrm{ml}$ of $\mathrm{NaCl}$ isotonic solution, vortex slowly to homogeneous. Take $0.5 \mathrm{ml}$ mixture solution was poured into media Brucella blood agar + vitamin K (BBK) agar, put in jar anaerobic by gas pack anaerobic, incubation at $37^{\circ} \mathrm{C}$ for $48 \mathrm{hrs}$.

Identification of the anaerobic bacteria carried by staining Gramnegative bacteria. Slides are sequentially stained with crystal violet and iodine then destained with alcohol and counter stained with safranin. Anaerobic bacteria such as $P$. gingivalis and F. nucleatum that cause halitosis used as standard. The anaerobic bacterial culture obtained was transferred into BBK agar slant. Culture was inoculated by stabbing into the agar butt (bottom of the tube) with an inoculating wire and then streaking the agar slant in a wavy pattern. It was incubated for
$3 \times 24 \mathrm{hrs}$ at $37^{\circ} \mathrm{C}$ in anaerobic condition. Close the tube containing the bacterial culture with a swear rubber that has been sterilized. Each a cap tube inserted needle, the needle tip was attached sterile paper disks (Fioroni paper with diameter $12.7 \mathrm{~mm}$ ). The tube is sealed, and the top of the needle was attached tap to regulate air travel; the tap was opened before incubation. All bacterial inoculation tubes then inserted in the jar and incubated under anaerobic conditions at $37^{\circ} \mathrm{C}$. After incubation for $3 \times 24 \mathrm{hrs}$, the tube removed from the jar, and the taps are closed quickly; VSC gas in tube inoculum bacteria was taken using a $3 \mathrm{ml}$ syringe and dumped the gas as much as $2 \mathrm{ml}$, residual gas present in spoit $(1 \mathrm{ml})$ then injected into GC-OC under conditions instrument was temperature of $36^{\circ} \mathrm{C}$, and the flow rate was $14.3 \mathrm{cc}$ (gas). The value of VSC of methyl mercaptan (average scores) was $>2.4 \mathrm{ng} / 10 \mathrm{ml}$ or 180 parts per billion stated halitosis [12].

Halitosis activity in vitro is done by measuring the gas of VSC of methyl mercaptan produced by bacterial culture, which is done before and after administration of the extract. Extract at a dose of $20 \mathrm{mg} / \mathrm{ml}$ was injected through a needle in the lid of the tube inoculation and allowed to stand at room temperature up to $6 \mathrm{hrs}$; then, methyl mercaptan VSC value was measured again at the GC-OC. Catechin used as a standard against the extracts.

\section{RESULTS}

SBF ethanolic extracts have been macerated, then partitioned with several solvent to separate the extract based on polarity, and obtained phytochemical identification by following data (Table 1), and TPC data are shown in Table 2 .

Halitosis activity against VSC of methyl mercaptan of SBF extracts Halitosis activity measured based on inhibition of methyl mercaptan gas that produced by anaerobic Gram-negative bacteria culture from saliva using GC-OC before and after the administration of the extracts of the SBF (Fig. 1).

\section{DISCUSSION}

S. burahol (Blume) Hook.f. and Thomson tree is famous as kepel or burahol. Burahol fruit is one of the rare fruits in Indonesia. S. burahol is one of some Indonesian indigenous plants. The SBF powder was extracted with ethanol $96 \%$ using maceration method to avoid damage to thermolabile compounds, which damage due to high temperatures. The ethanol solvent can attract chemical substances which are polar

Table 1: Phytochemical screening of SBF extracts

\begin{tabular}{llllll}
\hline \multirow{2}{*}{$\begin{array}{l}\text { Chemical } \\
\text { content }\end{array}$} & \multicolumn{3}{c}{ Extracts } \\
\cline { 2 - 6 } & \multicolumn{7}{c}{$\begin{array}{l}\text { Ethanolic } \\
\text { acetic }\end{array}$} \\
\hline Alkaloid & - & - & - & - & - \\
Saponin & + & + & + & + & - \\
Flavonoid & + & + & + & + & + \\
Terpenoid/sterol & + & - & + & - & + \\
Tannin & + & + & + & + & + \\
Glycoside & + & + & + & + & + \\
\hline
\end{tabular}

+: Detected, -: No detected, SBF: Stelechocarpus burahol fruit

Table 2: The TPC of SBF extracts

\begin{tabular}{ll}
\hline Extract & TPC (mg GAE/g-DE) \\
\hline Ethanolic & $4.3591 \pm 0.011$ \\
Ethyl acetate & $4.901 \pm 0.021$ \\
Butanolic & $2.382 \pm 0.003$ \\
Water & $6.953 \pm 0.102$ \\
Methanolic & $1.284 \pm 0.006$ \\
\hline
\end{tabular}

mg GAE/g-DE: Milligram gallic acid equivalent/gram dry extract,

SBF: Stelechocarpus burahol fruit, TPC: Total phenolic content 


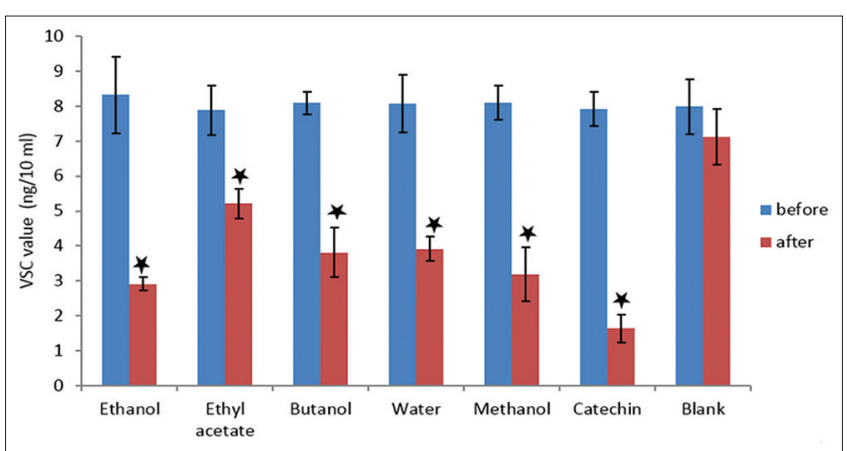

Fig. 1: VSC methyl mercaptan values before and after treatment of the SBF extracts with doses concentration of $20 \mathrm{mg} / \mathrm{ml}$.

*: significantly different compared with the control group (-) (distilled water) and catechins with $p<0,05$ (statistic with anova).

and non-polar contained in burahol fruit. High levels of sugar in the SBF make that the extract obtained is hard dried, to remove residual solvent in the extract, then the ethanol extract condensed in evaporation in a vacuum oven at a temperature of $60^{\circ} \mathrm{C}$, a pressure of 15 atmospheric, for 2 weeks. The extract was partitioned using different solvents to separate the extract based on polarity. Ethanol crude extract was partitioned with n-hexane solvent which represents the non-polar solvent, to obtain non-polar extract, while ethyl acetate, butanol, water, and methanol were used to obtain the extract with polar chemical components.

The phytochemical screening test was not performed on the n-hexane extract because it does not provide a decrease in activity of methyl mercaptan compound (data are not published). The identification of chemical components of SBF extracts showed that saponins were found in the ethanol, ethyl acetate, and water extract. The presence of secondary metabolites such as tannins, flavonoids, glycosides, and terpenoid component was found in all SBF extracts.

Determination of total phenols content (tannins and flavonoids are polyphenolic compounds that are classified) performed using gallic acid as a standard and Folin-Ciocalteu reagent. TPC extracts were determined based on the ability of phenolic compounds in the extract with phosphomolybdic-phosphotungstic acid reagent, Folin-Ciocalteu reagent (yellow) will change the color to blue. The intensity of color formed was measured at a wavelength of $765 \mathrm{~nm}$. Gallic acid was used for the calibration curve and was plotted at $0.05,0.1,0.15,0.2$, and $0.25 \mathrm{mg} / \mathrm{ml}$, gallic acid that was prepared in methanol ( $70 \% \mathrm{v} / \mathrm{v})$. Water extract showed the highest TPC than the other extracts; this is relevant to reference, the phenol include polar compound has high solubility in aqueous solvent. The higher the content of phenol (phenolic hydroxyl group amount) in the sample, meaning the higher the absorbance of the solution. The polarity solvent level to determine the structure and the type of phenolic compounds extracted. Phenolic compounds which have more hydroxyl groups will result in a high TPC [17].

Halitosis activity in vitro is done by measuring the absorption of volatile methyl mercaptan using GC-OC; methyl mercaptan is produced by anaerobic oral bacteria from saliva of physiologic halitosis participants. Saliva of participants was taken in early morning when participants wake up $(05.00 \mathrm{am})$ because the production of saliva decreases during sleep so that the growth of anaerobic oral bacteria such as P. gingivalis and F. nucleatum increased [18]. This is a favorable factor for the formation of VSC and the main cause of bad breath odor when the participants wake up (morning breath). Halitosis activity to inhibiting or reducing VSC of methyl mercaptan level was measured before and after administration of the extracts with dose of $20 \mathrm{mg} /$ $\mathrm{ml}$. The VCS of methyl mercaptan measurement results shows that the ethanol extract of SBF has absorption capability against methyl mercaptan which is higher than the other extract, with value of the average percentage reduction in methyl mercaptan is $64.95 \pm 0.82$, which followed by methanolic extract is $60.51 \pm 0.03$, butanol extract is $52.82 \pm 0.15$, water extract is $51.49 \pm 0.43$, and the ethyl acetate extract is $33.92 \pm 0.18$ while catechin as control is $79.34 \pm 0.29$. Data obtained in this study were calculated of statistical using Shapiro-Wilk method because the sample size is $<50$ and the calculation is continued using analysis of variance (ANOVA one-way). The VSC values between the treatment groups, before and after administration of a dose of the extract with a dose of $20 \mathrm{mg} / \mathrm{ml}$, were significantly different, whereas the treatment group compared with catechin as a standard also significantly different, with $\mathrm{p}<0.05$.

The use of herbal medicine products to eliminate bad breath in works by: (1) Cover up the odor (masking effect), (2) eliminate or inhibit the activity of VSC-producing bacteria, (3) reduce or inhibit VSC compounds that cause bad breath, and (4) odor-neutralizing chemicals in mouth [19]. Our results showed that SBF extracts had also reduce or inhibit VSC that cause bad breath. The effect occurs because phenolic compound such as tannin, flavonoid, and glycoside in SBF extracts. Phenolic compound as like as catechin in green tea could reduce VSC concentration in the mouth air and could also inhibit VSC production in a saliva-putrefaction system [20]. Catechin can transform VSC to nonodorous compounds through the reaction with sulfhydryl and amino groups of VSC [21]. Proanthocyanidins (a flavonoid group) in grape have a potential as an adsorbent of methyl mercaptan that cause bad breathe [22]. Phenol derivatives in some vegetables and fruits such as varigatic acid and cafeoil cuinic acids have odor remover activity by binding to sulfhydryl compound $[23,24]$. The mechanism of the phenol compound is by conjugating of compounds with sulfhydryl groups [25-27].

\section{CONCLUSION}

All extract of SBF (ethanol, ethyl acetate, butanol, water, and methanol) can inhibit and reduce VSC of methyl mercaptan causes of halitosis. Our finding showed that $S$. burahol could be useful as a natural agent for the treatment of halitosis.

\section{ACKNOWLEDGMENTS}

We wish to express our gratitude to Directorate of Research and Public Service University of Indonesia for the Excellent Research Grant University - 2016.

\section{REFERENCES}

1. Tonzetich J, Ng SK. Reduction of malodor by oral cleansing procedures. Oral Surg Oral Med Oral Pathol 1976;42(2):172-81

2. Tangerman A. Halitosis in medicine: A review. Int Dent J 2002;52 Suppl 3:201-6.

3. Hughes FJ, McNab R. Oral malodour - A review. Arch Oral Biol 2008;53 Suppl 1:S1-7.

4. Nachnani S. Oral malodor: Causes, assessment, and treatment. Compend Contin Educ Dent 2011;32(1):22-4, 26-8, 30-1.

5. Tonzetich J. Production and origin of oral malodor: A review of mechanisms and methods of analysis. J Periodontol 1977;48(1):13-20.

6. Tomás Carmona I, Limeres Posse J, Diz Dios P, Fernández Feijoo J, Vázquez García E. Extraoral etiology of halitosis. Med Oral 2001;6(1):40-7.

7. Scully C, Greenman J. Halitosis (breath odor). Periodontol 2000 2008;48:66-75.

8. Schmidt NF, Missan SR, Tarbet WJ. The correlation between organoleptic mouth-odor ratings and levels of volatile sulfur compounds. Oral Surg Oral Med Oral Pathol 1978;45(4):560-7.

9. Heyne K. Useful Plants Indonesia. Translator by Forestry Research and Development Agency. Vol. 1. Jakarta: Forestry Research and Development Agency; 1987. p. 765.

10. Darusman HS, Rahminiwati M, Sadiah S, Batubara I, Darusman LK, Mitsunaga T. Indonesian kepel fruits (Stelechocarpus burahol) as oral deodorant. Res J Med Plant 2012;6(2):180-8.

11. Munim A. Development of Nutraceuticals: Moringa oleifera Leaves and Stelechocharpus Burahol Fruits, $2^{\text {nd }}$ International Conference on Nutraceutical and Cosmetic Science, Jakarta; 2013. p. 32.

12. Murata T, Rahardjo A, Fujiyama Y, Yamaga T, Hanada M, Yaegaki K, et al. Development of a compact and simple gas chromatography for oral 
malodor measurement. J Periodontol 2006;77(7):1142-7.

13. Indonesian Ministry of Health $(\mathrm{MOH})$. The Standardization Extract Parameters. Jakarta: MOH; 2000

14. Trease GE, Evans WC. Pharmacognosy. $12^{\text {th }}$ ed. East Bourne: Baillier Tindall, ELBS Publication; 1996. p. 344-539.

15. Tyler VE, Brady LR, Robbers JE. Pharmacognosy. $9^{\text {th }}$ ed. Philadelphia, PA: Lea and Febiger; 1993. p. 59-64.

16. Singleton V, Rossi J. Colorimetry of total phenolics with phosphomolibdic-phosphotungstic acid reagents. Am J Enol Vitic 1965; $16: 144-58$.

17. Harborne JB. Methods of Phytochemicals, Guidance How Modern Plant Extract. Translated by Padmawinata. Bandung: ITB; 1987.

18. Sanz M, Roldán S, Herrera D. Fundamentals of breath malodour. J Contemp Dent Pract 2001;2(4):1-17.

19. van den Broek AM, Feenstra L, de Baat C. A review of the current literature on aetiology and measurement methods of halitosis. J Dent 2007;35(8):627-35.

20. Lodhia P, Yaegaki K, Khakbaznejad A, Imai T, Sato T, Tanaka T, et al. Effect of green tea on volatile sulfur compounds in mouth air. J Nutr Sci Vitaminol (Tokyo) 2008;54(1):89-94
21. Yasuda H, Aragawa T. Deodorizing mechanism of (-)- epigallocatechin gallate against methyl mercaptan. Biosci Biotechnol Biochem 1995;1(59):1232-36.

22. Jun Y, Tokutake S, Kikuchi M, Kubota Y, Konishi H, Mitsuoka T, et al. Effect of proanthocyanidin-rich extract from grape seeds on human fecal flora and fecal odor. J Microb Ecol Health Dis 2001;13:25-31.

23. Negishi O, Negishi Y, Ozawa T. Enzymatic deodorization with variegatic acid from (Boletus subvelutipes) and its mechanism. Food Sci Technol Res 2000;6(3):186-91.

24. Negishi O, Negishi Y, Yamaguchi F, Sugahara T. Deodorization with kuding-cha containing a large amount of caffeoyl quinic acid derivatives. J Agric Food Chem 2004;52(17):5513-8.

25. Negishi O, Negishi Y. Enzymatic deodorization with raw fruits, vegetables and mushrooms. Food Sci Technol Res 1999;5(2):176-80.

26. Negishi O, Negishi Y, Ozawa T. Effects of food materials on remoral of allium-specific volatile sulfur compounds. J Agric Food Chem 2002;50(13):3856-61.

27. Negishi O, Negishi Y, Aoyagi Y, Sugahara T, Ozawa T. Mercaptancapturing properties of mushrooms. J Agric Food Chem 2001;49(11):5509-14. 